\title{
YESTERDAY AND TODAY: THE TASK OF THE UNIVERSITY
}

The university has become a battlefield of the mentally violent as to the question of the part the university should play in modern industrialised society, in the communication between rich and poor, in the spiritual confusion that followed the lapse of Christianity. The old idea that the university is and should be the place where intelligent people withdraw for the purpose of autonomous, unengaged, religiously and politically unprejudiced, impartial theoretical thinking, is struggling for its life against the growing belief that the powers of theoretical thinking are no more than instruments for, and should not be used otherwise than, the purpose of changing society to one which is more just, more human, than the prevailing (capitalistic) structure. Rejecting the intimidative ways sometimes followed by both sides in defending their case, I do have sympathy with both sides: I still find enough reason(s) to believe that the university is somehow something different from a church or a political party or a pressure group, while knowing that the university never has been or could be, and firmly believing that it should not be, utterly aloof from human life in its fullness; and therefore I am prepared to advocate that the university ought to cultivate its relation to surrounding society, but in a way adapted to its own peculiarities, for the university may not outlive (as university) its being instrumentalized. The battlefield mentality ought to be exchanged by one of thoroughgoing philosophical reflexion by all people interested in the university's affairs. Knowing that they fulfill their fallible work within the cadres of a meaningful history in which also the university came to be, they should ponder, in the light of the continuity and discontinuity of history, about the task of the university of yesterday, of today and of tomorrow, in a non-exclusive disjunction.

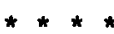

It could be that the contemporary structuralistic (including calvinistic) reader would ask: "Why concern yourself with the task, and not, as for instance the calvinist Dooyeweerd has done, with the structure of the university?" Concerning oneself with the 'structure' would 
then mean searching for some universal idea, some architectural blueprint, some cosmogonical ratio seminal is which serves as universal law all universities of all times have to obey. But we are radically separated from the primeval order and from every clear insight into societal structures that could have been supposed to be part of living in such an order; and an unmystical, nonspeculative epistemological way of transcending our historical order to a vision of this suprahistorical structure has not yet been offered.

Nevertheless, some definition of 'university' must be given, that is, if it is supposed to mean something specifically as name for some existing societal institution. And those Christians, who dare (as consequence of their belief that human life is included in its full extent only in its covenantal (religious) bond with God) accept that although man's life should be an integrated whole, any historical association tending to become totalitarian should be rejected as substitute religion, need some such definition all the more to serve as (relative) normative criterion according to which the (possibly) not differentiating but totalitarian or desintegrating ways of the university could be judged. T S Eliot rightly rejects totalitarianism as being unchristian (see Ea, 7-26); but the dilemma of his position is that he does not explicate the differences among societal relationships (such as state, church, educational institutions) so that we stay in the dark about the borders. Dooyeweerd, on the other hand, believing that ".. it is impossible to detect firm boundaries between the different types of societal relationships if we do not penetrate behind the social forms to the internal structural principles positivized by them" (Df, III, 175), but also maintaining that "as to undifferentiated societies, ... their types of societal relationships also have structural principles, determining their inner nature, and differing fundamentally from those of differentiated types" (Df, III, 171), has thereby petrified societal development. For having founded both undifferentiated and differentiated societies on fundamentally different principles in God's world-order, he has made it impossible to show why anyone should promote societal differentiation, and so uprooted his own theory of the historical opening process. Regarding his theory of the differentiated society, since every institution of our society is based in Dooyeweerd's theory on some struc- 
tural principle sovereign in its own sphere, although bound to all others by a relational entanglement called 'enkapsis' (Df, III, 170), the question remains whether his analysis is not a hypostatization of the contemporary status quo, and whether the philosophical categories in terms of which his analysis is built up will outlive the test of time and societal change.

The only alternative left is to search out the history of the university for a concrete universal (maybe a contradictio in terminis to some), peculiar to all universities, that shows how they differ from all other societal institutions.

Yet how do you search without knowing what to search for? The university presents itself within the horizon of human experience as an institution (an organization of people) where people work. We may ask them what they do, and why, and provided that they do not form some sort of secret brotherhood, we may hope for intelligible answers. We may read through their archives with the same questions in mind, and hope to find the answers their predecessors would have given. If their being organised in an institution ever had any meaning, we may hope to find some convergences in the answers; and, not having categorised the university beforehand in terms of structural-analytical categories, we may even hope to have retained a little bit of openness to detect possible variability in the answers. The answers to the question what is being done by the members of the university, and why (meaning not their ultimate but their most direct aims), will tell us what task they undertook as a group.

What results then, does the historical study of the task of the university produce?

It seems difficult to distinguish the mediaeval university from the cathedral school that belonged most directly to the church. The university itself had no independent authority, and had to bend constantly before the powers of a church that tended to become a totalitarian power structure. Both university and cathedral schools existed as institutes for teaching; and they had more or less the same educational set-up, namely a basic study of the liberal arts, followed by some preparation for an occu- 
pation, while the university had post-graduate faculties besides theology. The difference showed itself most clearly when Abaelard tried to free himself from the authority of the cathedral schools by putting up a private school with the aim of doing his own critical research without being forcibly bound to the authority of the church (see e g the Prologue to his Sic et Non, or the passage quoted from his Historia calamitatum, Wa, 130ff). Rather the same mentality could be seen in the quaestiones disputatae, and in the courage St Thomas showed in making a synthesis between christian doctrine and aristotelianism in the face of violent resistance. While the church schools trained their students in a dogmafavouring way, the university, though bending to the dogma, aimed at a relatively free confrontation of the widest possible field of research, giving a logical qualification to its work (see e g the methodology of Petrus Peregrossi, - 1250 a D; Wa, 165). Many factors, such as their respect for authority, scarcity of books, the influence of the chu rch, etc, added up to the result that the relationship of the two basic elements of the academic community (namely, masters and students) had in general been based on "the student's capacity and the teacher's industry" (John of Salisbury, Carnotensis Metalogicon; Wa, 126). But intensive study warrants the conclusion that the mediaeval university really had been "an association ('universitas' mean 'organised body' $-\mathrm{J} \mathrm{J} \mathrm{V}$ ) of masters and scholars established in some place with the intention to study the sciences" (from the Siete Partidas, 1263 a D, of King Alphonse of Castile, Wa, 184); in other words, it had been a community in which some persons had the responsibility of training others to acquire the scientific habit by leading them into confrontation with the process of logically qualified research on a philosophical basis.

After the middle ages the university declined from its important position, but reached another peak in its history in Germany at the beginning of the nineteenth century.

According to, Fichte, the German idealist, the university had to concern itself with the training of students, not to know facts, but to use their intelligence in practical life in a critical way. By 'critical' he did not mean 'polemical'; but he meant that the student, on the basis of a (to be read: 'Fichte's') philosophy, had to work himself into the 
materials of the special sciences. The scientist (not to be read: 'natural scientist') sees in his scientific work an end in itself, and ought to study in isolation. When one should have asked him how the latter agreed with his aim that the student had to be trained to use his intelligence practically, he would have answered: "... er wird einst, als vollendeter Gelehrter, in welcher Weise er auch künftig sein wissenschafliche Bildung im Leben anwende, in jedem Falle allein in der Idee die Wurzel seines Lebens haben, und nur von ihr aus die Wirklichkeit erblicken ..." (Fa, 16). To him, good scientific training, by a good philosopher-pedagogue who understood the socratic way of dialogical teaching, guaranteed good cooking without any practical training (sic! - Fa, 46). He, no doubt, saw his training of "wissenschaftlicher Künstler" as training of the most important aspect of the student's life, and therefore his scientifical training was seen as education in the most extensive sense of that word.

Schleiermacher, Fichte's fellow idealist, allowed for a bit more polemical freedom in the university. For he accepted a suprapersonal reasonable spirit/mind (Geist) that leads mankind in searching for truth, and under its leadership new paths could be found, the exploration of which should not be suppressed. The university was assigned the task to awaken the scientific spirit in the student by educating him philosophically, that is, leading him in the socratic way to insight in to the laws of reason and the necessary coherence of all knowledge, which follows "aus der unmittelbaren Anschauung der Vernunft und ihrer Tätigkeit" (Sa, 139). On the basis of this universal insight the student would be able to search into the special subjects. The university fulfills its task on the crossroads where factualistic school education ends in philosophical systematization, and from where the ways to particular occupational training or specialised work in a research academy begin. He defined "die Schule als das Zusammensein der Meister mit den Lehrburschen, die Universität mit den Gesellen, und die Akademie als Versammlung der Meister unter sich." Two important aspects may be drawn to the fore: The university has the task to train apprentices ("Gesellen"!) in science through direct contact with the working process of reason, and this amounts to educating man as man. 
A(nother) contemporary of Fichte, Wilhelm von Humboldt, also saw a relation between the scientific training of the university and cultural education (in the broad sense), but he did not follow him in identifying the latter with the former. According to Von Humboldt the university has the task connecting objective scientific research to the inner sediment of school education in the student, as well as to lead the student into manifesting knowledge already acquired by doing research on his own. About the relationship of master to student he say s: "Der ersterer ist nicht für die letzteren. Beide sind für die Wissenschaft da ..." (Vc, 256). If the university (and also the research academy) could hope for any success, it could only be by confronting all its members with the "reinen Idee der Wissenschaft" (Vc, 255-6), which presupposed, according to Von Humboldt, seclusion from surrounding society and freedom within the academic circles; but real spiritual work could only grow when the academic corps worked together, "damit die gelingende Thätigkeit des Einen den Anderen begeistere und Allen die Allgemeine, ursprúngliche ... hervorstrahlende Kraft sichtbar werde ..." (Vc, 255-6). And this working together, by master and student, constantly in search for the ideal truth, contributed to the cultural building up of the whole nation and of all mankind. Therefore in the end specialization had to be transcended, and faculties had to work together, thus helping mankind to reach immortality.

It has sometimes been said that these idealists made the university into an ivory tower, totally aloof from surrounding society. But this is not true. They all believed that the university supplied the peak of education by forming the most important human function, namely reason. They were so naively rationalistic as to believe that scientific training (in their sense) was all one needed to carry out the highest societal responsibilities successfully. The task of the university was to train the apprentices of science in community, which meant to Fichte and Schleiermacher, less to Von Humboldt, leading men to their destination as man.

These same basic ideas are to be found around World War Two existentialistically interpreted by Karl Jaspers, in the sense that intellectual training would lead man to his supra-intellectual destination of existential freodom. 
However, Jaspers wisely realised that scientific training does not guarantee occupational success, and can serve only as preparation for a job. He, following his idealistic predecessors, rejected the idea that the university had to supply occupational training courses, and held on to the tradition that university courses should be strictly scientific. He wrote: "Lehre heisst teilnehmen lassen am Forschungsprozesses"; and as to the researching teacher: "Er allein ist lebende Wissenschaft, und im Verkehr mit ihm ist die Wissenschaft, wie sie ursprünglich existiert, anschaubar. Er weckt gleiche Impulse im Schüler. Nur wer selbst forscht, kann wesentlich lehren" (Ja, 68-69).

In this whole context the work of the nineteenth century liberal catholic thinker, Cardinal Newman, should not be forgotten. Although more reserved as to the effects of university training outside the university, he also accentuated the intellectual, scientific training through the acquisition of universal (philosophical) knowledge in a study community. He hoped that this might eventually raise the intellectual tone of society, thus furthering civilization, and help people to find their way back to the church; though he explicitly rejected the idea that the university itself should search for new knowledge.

These ideas about the task of the university were also in a sense realised in practice, being ideas of people most directly connected with the university in action. Thus we may conclude that the european university, from the middle ages up to about World War Two, found its task to be the scientific training of students, by confronting them with or letting them take part in the process of scientific research. This did not mean that the university stayed fully outside the political and religious arena. According to Fichte and Schleiermacher, the university's products were in fact the (German) political elite, and religion had to be reformed by them on a universal scientifical basis. Even Von Humboldt, then minister of education, saw in the university an object of German national prestige. The university changed its international mediaeval character, but fell into the hands of the national state. One of the reasons stated for the founding of the Free Christian University of Amsterdam was that the totalitarian liberalist state, in co-operation with liberalist academicians, appointed only liberalists in academic posts. 
blocking the way to better qualified (but confessing) Christians and Jews. Politicians and professors thought alike, and the church had withdrawn from 'public' affairs long before.

Another view of the task of the university presented itself in nineteenth century America. Kerr tells us that the university there, answering to the quest for schooled labour, started off with occupational training for many different types of work. The university became directly implicated through its courses, finances, advisors, in the affairs of industry, labour unions, politics and the government. Kerr welcomes this development, as consistent with the surrounding society; he realises, however, that the result is not a university in the sense of an academic study community, but a non-homogeneous assembly of subcultures with a common administration. This 'multiversity' of his is no longer a definable institution; it has simply become part of the national, capitalistic, economic purpose. He formulates it this way: "Knowledge is now central to society. It is wanted, even demanded by more people and more institutions than ever before. The university as producer, wholesaler and retailer of knowledge cannot escape service. Knowledge, today, is for everybody's sake" (Ka, 114). The university's only task is to be the prime instrument in the production of knowledge and experts needed for all sorts of manipulation; and what type of knowledge and experts are produced depends 'on the needs of society' (to be read: 'industrial, political, military interests'). Kerr entitled his book: 'The uses of the university'.

In reaction to the situation sketched in that book, another American, $H E$ Barnes, recently wrote a book called: 'The university as the new church'. She finds some (superficial - I think) resemblance between the modern American university and the (mediaeval) church: "It would be possible without undue violence, to sum up the goals of each in identical terms: to point out the path to truth, to instruct the young, to guide man toward the good life" $(\mathrm{Ba}, 2)$. The church has been done with, and the university is the only institution that is able to supply a new value system, a new secularised religion, for mankind. The university cannot claim to be concerned only with the neutral transmission of knowledge, for it has already become, and has been for a long time, involved with social 
change. "I seriously propose that the university should become the new church. It is my conviction that it has long been functioning as a church, by which I mean that it has defined truth and human good and taught values as well as knowledge for many years but surreptitiously and without knowing the fact.... This man-made religion is what the students are demanding, and the university is the institution which must give it shelter and ensure its survival and future growth" (Ba, 35-36). Her analysis of the factual situation amounts to the same as that of Kerr. But she tries to unify the different parts of Kerr's knowledge factory by founding it upon an explicit valuesystem on the basis of which its all-embracing task could be fulfilled. In her prophetic eyes the university is to become the leader of man towards eschatological selftranscendence.

In Europe the situation is also changing. Although the European universities never became as deeply involved in societal problems as those in America (or ours in South-Africa!), the ways of Nazi Germany and international capitalism opened the eyes to the implicit values at work in the university. So a reaction set in after World War Two; a reaction based on distrust of any existing power structure; a reaction against the sterility of positivism, seemingly content with descriptive analysis; a reaction against abusive instrumentalising of the university by political or international industrial powers. Horkheimer, the Neo-Marxist, therefore proposes to reform the university into a philosophical, critical, occupational training centre, where the student, in our barbaric age, as in a micro-society, can regain the remembrance of humanity. But let us not be deceived by the term 'philosophical'; he recognizes only homoeconomicus: "Ich glaube, dass über die ernstesten Fragen der Philosophie, über die Totalität des Lebensprozesses, in welchem die Menschen nur ein Moment sind, nur der wirklich Urteilen kann, der eine Bilanz zu lesen versteht. Dadurch aber wird nicht der Bilanzfachmann von selbst zum erben der Philosophie. Den Studenten der Nationaläkonomie ist der Verantwortung auferlegt, die technischen Kenntnisse, die sie erwerben, zu messen an den Strukturgesetzen der Wirtschaft als Ganzes, in der die Techniken gelten" (Hb-1, 12-13). And Regtien, the (former student) activist in Holland, tells us that there exists a relation between the (politically surely not neutral) 
profit principle in our society and fundamental research, via the applied sciences which are based on fundamental research; and apart from that, even the individual research worker enters the university with his implicit political pressuppositions: "Waar het de Kritische Universiteit om gaat is de confrontatie van de naieve weten schappelijke vakcycloop met deze toe stand. Zodat een discussie kan ontstaan over de wenselijkheid, de juistheid of onjuistheid van de impliciet aanwezige politieke doelstellingen in het wetenschapsbedrijf. Dat is de politisering die de universiteit in opstand door zal moeten maken. Dat is de politieke universiteit die wij willen" (Ra, 76). But, surely, discussion of the implicit political purposes of science is not the only form of politicized university he wants. The political discussion (if what happens in practice could still be called 'discussion') surely is not the final goal of Regtien c s. This discussion is only the beginning of the road to an ideologized university which could be used to change society. He does not forget to add: "Er is een nauwkeurig doordacht actieplan op basis van een fundamentele analyse van de eigen situatie nodig, uitgewerkt in een serie eisen tot verbetering van de situatie, waarbij die eisen getoetst zijn aan het criterium dat alleen datgene als werkelijke verbetering wordt gezien, wat de weg naar nog niet bereikte fundamentele veranderingen openhoudt ... de enige mogelijkheid te voorkomen dat de studentenacties terecht komen in de doodlopende straat van integreerbare corporatieve eisen" (Ra, 144). He invites students to refrain from propagating an utopia, but to infiltrate all sectors of society on the basis of the this way of action.

The university has become or is becoming totalitarian. Barnes says: ".. it is evident that the university is fast becoming the centre of community cultural life. It keeps distinguished writers and artists on its payroll. For the general public, it provides drama, concerts, lectures, artistic productions of all kinds, created either by its own members or by those travelling groups or individuals who are paid to come and perform. As the root of the meanings of the words suggest, the catholic church and the university have, each in its turn, undertaken to minister to the whole of society and to unify all aspects of human activity" (Ba, 20-21). It had, until recently, the well- 
defined, specific task to train students into acquiring the scientific habit by bringing them into contact with, or letting them take part in the process of scientific search for truth. Now it tries to lead the way to the good life.

No, I am wrong! It became totalitarian long ago. For there are two types of totalitarianism: The one we find where a societal organisation acquires more and more tasks, unrelated to the task it originally stood for; and the other is to be found where an organisation defines its task clearly, but then tries to incorporate other possible activities into its original task, thus (e g) reducing those other activities, regardless of what they are, to derivatives of this one and only meaningful area of activity (Fichte, c s).

How should we react to the various options which history offers? Should it be the task of the university to educate people in an all-inclusive way? Or must it be a service institute, manufacturing knowledge, or an instrument for changing surrounding society? Or should we stick to the simple task of training apprentices to acquire the habit of searching for the truth in a scientific way?

The task of the university has until recently in Europe been seen as the transmission of the scientific habit. The situation is changing, and in many circles, including Christian circles, the tendency is developing to define the task of the university in a way that implies all-inclusive education of the student. The Christian thinkers who go this way feel the same need felt by Barnes on the secularist side: young people must be assisted to fight the cultural desintegration that followed the disappearance of a common value system, - a disintegration that at times makes our lives unbearable in a very complex society. This problem is real, no doubt. Such has been the view of De Klerk (De, 79-103) when he said that the task of the university was to cultivate and motivate the student in the centre of his being. Although still maintaining scientific training as the kernel of this education process, he does go as far as saying that the university (as such) has the task even to reorganise students' extramural activities. This seems to be the view also of Taljaard (Ta, 440) when he says that the extramural 'student life' is qualified by the structural principle of the university itself. But we know already from the history of the 
American university that this may end up in a competition of scientists with football stars for breathing space at the university. Because of the number of people involved the university simply does not have the basis of mutual trust to be able to engage in real character forming, which could imply such intimate questions as sexual guidance. And how does Taljaard harmonize his subjecting the students' non-academic activities to the structural principle of the university with his explicit exclusion of the lecturers' non-academic activities therefrom? Their point of view does contribute to the integration of human life; but by not balancing it by stressing and working out the way of differentiation, the result may be a totalitarian university, and it may well be a threat to the students' own responsibility in their non-academic life.

Granted that the revolutionary students really are searching for justice, we have two ways in which the university could be a service institute for surrounding society: it can serve the needs of the status quo; or, in reaction against the first, it can serve the need for soci etal change. There are also Christian thinkers who find this type of view on the university's task very attractive, because it could serve as a channel of love and Christian influence on social affairs. Thus Professor Notohamidjojo from Indonesia, with reference to the revolutionary clash of eastern and western cultures in Asia, says that the Christian university has a poor-relieving task in the sense of demythologizing and de-ideologizing politics and culture, combined with the task of occupational training in the insecure Third World situation so that there might be people who understand their post as a situation to practise their calling (Nc, 33-40). Symons and Moberley say that most people spend their whole lives in jobs, and the university should train them to that end (Sg, 36-37; Ma, 172). But we know from the American situation, which is the result of an attempt to answer precisely the problem posed by Notohamidjojo, that the university tends to disintegrate that way: only some subjects, those needed at the moment, are judged worth while studying and spending money on; and precisely the throroughgoing thinking, which the Christian university so dearly needs, bleeds to death next to the speedy production of needed trained workers. And a (Christian) university that sides with a (Christian) political party, or with the status quo, or the revolutionaries, not only creates tensions in 
its members (for they may differ from it on social questions), but endagers its own free political judgement, and may lose its educational integrity and end up being totalitarian itself. The first thing to be crushed down in such a situation is the peaceful communal searching for the truth. Surely, the university does, and ought to serve society; but it does so when its members publicly uncover the norms that ought to be obeyed by all of us, and train the students to search for those norms in whatever life situation they may be. But uncovering norms means changing the world in a persuasive way. This not only integrates the university into society in a way adapted to its old traditional task but also respects the proper responsibility in non-academic life of all involved. The latter is the way proposed by the nineteenth-century Christian idealistic thinker Schroff (Sf) but also that of the contemporary Visser ' $t$ Hooft (Vi). Moreover, the only way I can see in which the university will be able to attack the problem of misuse of scientific discoveries is the training of norm-conscious students, who may influence others to be responsible in their word. After all, the democratization of the university and industry which the activist students are struggling for is in itself no guarantee that responsible decisions will be taken.

I can imagine that somebody at this stage may ask why I favour the older tradition about the university's task, thereby in fact pressing the question whether we ought to continue the simple scientific training of the student. This question can only be answered on the basis of a (short) analysis of the meaning of "scientific training."

As to the last question, I think we should first establish that drawing a painting of a tree is something different from analysing the biochemical functioning of the tree. Scientific research to which the latter belongs, is a peculiar tradition about the cultivation of the knowing process. Searching for truth about all that (one believes to) exist(s) by way of analysis based on logical arguments seems to me the most outstanding property of this tradition. It did at times pretend that it was itself the only way to truth. It also pretended to be impartial, universally valid, and claimed that all imagination and private belief, and the life and world views of the 'ordinary' people could and should be excluded from its searching process. Yes, it even pretended to be able to 
supply mankind with a new, rational religion. But if we could get rid of all those (in fact never realised and harmful) pretentions, and if understanding of the world could help us fulfil our calling, what would hinder us from continuing that tradition, and handing it over to others? This confronts us with the question of the relation between scientific research and the 'educational' process in the university.

The mediaeval university trained its students philosophically and specialistically (in relation to the 'higher' occupations of that period) in a logical-critical way; but there existed a discontinuity between the teaching situation and the research work (the latter being limited to the masters). An analogical situation seems to exist in American universities, where the 'brightest' staff members occupy research chairs, so that the higher a man's standing, the less he is concerned with the students who are running from classroom to classroom following specialized courses.

The European tradition attained its own insight into the pedagogical side of university work, to be found in the propagation of a dialogical master-apprentice relationship by the idealistic thinkers as well as in Jaspers' view that university teaching means to let students take part in the process of scientific research. And all of them hereby meant specialized research on a philosophical . Von Humboldt may be excepted as to the 'philosophical' basis. They understood, I think, that the student's taking part in the process of research under the inspiring leadership of an able scientist is the best way to help somebody to become an independent, responsible research worker himself. Really and seriously seeking for the truth means coming to a standstill at the marvel in ordinary things ( $\mathrm{Za}, 1-3)$; and if the adjective 'socratic' might acquire any sense in Christian scientific training, then surely it must mean being confronted with God's world as a dazzling question mark. I do not see how we can hope to see students becoming adult thinkers and searchers as result of our training as long as we let training mean the transmission of facts from the lecturer's notebook to the student's notebook without passing through the mind of either. Searching for the truth presupposes an attentive alertness, never accepting anything as 'ordinary' or 'uninteresting', combined with a 
willingness to argue carefully and reverently the 'why?' of things. This habit is one that grows best in communication, where one thinker can point out to the other what he neglects or overaccentuates. In this relation the lecturer also is constantly growing, and will soon realize that he is to accept his student as (junior) colleague, if indeed we are to accept that the university is the place for scientific training.

History confronts us therefore with the possibility of a combination of philosophical (or general) training with specialized training, or simply specialized training, and both practised either bound to the classroom or in the research field itself.

The Christians Emmet (Eb, 12) and Coetzee (Cb, 6-7) have already warned against the (Fichtean) dogmatic way of inculcating one specific philosophical viewpoint as the only possible starting point of scientific training - a real danger in Christian circles - for this means an ideologising of some system in which all facts can be explained or explained away, and the latter amounts to nothing less than an idolatrous sterilization of the living question mark called creation. We might then, in a reactionary way, drift over to the other side and place the emphasis on specialization! However, the humanistic philosopher Gusdorf already warns us that the university as such has already disappeared, and only faculties are left over, because of the disregard of the problem which the philosophistic group tried to solve, namely the problem of the universitas scientiarum (Ga, 94-95). We can reach efficiency in manipulation of parts of the world; but the world is already punishing us (e g the pollution problem) for this fragmentary manipulation without understanding its basic relational structure. And those Christians who founded the Free University of Amsterdam saw that some vinculum scientiarum is needed if the student is to acquire a unified perspective (see e g Kb, 3133; Hc, 20-28).

After we have eliminated both extremes, granting Plato that it is practically impossible to know all things (Sophist, 234 A), scientific training could be a meaningful task for the university if, and only if, we could find a way to perspectivized specialization. Having lived for a long time among European student activists. I learned that 
their frustration at the absence of just this is one of the fundamental motivations that drives them on in a (sometimes) bitter struggle. Du Plessis has clearly shown that the patchwork called Studium Generale had no success in solving the problem (see Da, 5-55). Nevertheless, a solution exists: the intercommunication of scientists in the university; and, as Forrester-Paton teaches us, the courageous acceptance of the burning questions of life and world (be it air or water pollution, be it justice, or racism, nuclear warfare, or technical power) as legitimate questions for scientific study (Fb, 21-25); and - finally - the uncovering analysis of the hidden commitments at work in the scientific process (Bc, 19-20). In the Christian university the latter also means a constant but open critical discussion of our own basic commitments and the perspectives they are supposed to open to us, in order to transcend the grooves of one-track-minded specialism. If we reject this last possibility (perspectivized specialization), we reject the legitimacy of the existence of the university from a Christian point of view, which could for instance be done by making the argument plausible that one gets the best training in his daily job. But since this way of visualising the university's task obeys the norm of differentiation, inasmuch as non-scientific life is not reduced to or dominated by science; and since this also obeys the norm of integration, inasmuch as the posing of the burning questions make its work relevant to society; and since this way may succeed in transcending specialism, I can see no reason why this avenue could not be accepted as a meaningful task for the university. Or must we surrender the attainment of the scientific habit as meaningless?

We live in a time of cultural crisis. It is a time in which man has lost foundation and direction. It is a period of confusion and disintegration. It is a time in which one scientist says: "We scientists have got the right to play God" (E R Leach, quoted in Ba, 140), while the other trembles in fear for the dracula god-playing man has made. The actions of revolutionary students are not the tentacles of Moscow or Peking reaching for us; they are simply the cries for help of young people in distress. We need no more technocratic manipulators. What we need is calm, reflective, marveling and wondering thinkers with 
a perspective of hope and with the specialised knowledge they need to fulfil their calling and a willingness to help. The university is the only institution I know that has a tradition in training such people. For Christians, taking part in university affairs is therefore no less than obedience to the commandment of love. But we must be careful not to expect too much of this: this obedience cannot and may not amount to more than a little help; for man is not to be reduced to his scientific activity! It may never mean that the scientist takes over the responsiblities in the name of expertism; for the experts have already failed in their task. And one does not help somebody by taking all his responsibilities away, but only by training and encouraging him to bear them. Failures there always will be. Pray not to be discouraged by them.

J J Venter

JOHANNES JACOB VENTER was born in 1947 in Nylstroom (Northern Transvaal).

He studied at the Potchefstroom University for Christian Higher Education.

At: the Free University in Amsterdam he passed the doctoral examination ('doctorandus') in 1974. The core of this study was history of Logic and Philosophy.

At the moment he lectures in the Department of Philosophy of the Potchefstroom University for Christian Higher Education.

PRESENT ADDRESS: Sitastraat 10, Potchefstroom 2520, Republic of South Africa. 


\section{BIBLIOGRAPHY}

Ba Barnes, HE, The University as the new church, London. Watts. 1970 .

Bc Bailly, J, The mind of the modern university, University Pamphlets nr 1, ed R H Preston. London. SCM Press. 1946.

$\mathrm{Ca}$ Coetzee, J C, Die christelike universiteit, in Koers, XXI, nr 5, 1954, p 193-226

$\mathrm{Cb}$ Coetzee, J C. Ons universiteit, sy grondslag en beginsel en die vryheidsbeginsel, in Koers, XXI, nr 6, 1954, bylasg p 1.12.

Da Du Plessis. PGW. Gevraagde universiteit ... Port Elizabeth, University of PE, 1967.

De De Klerk, W J, Studentevorming, in Koers, XXXIV, nr 6, 1967, p 70103.

Df Dooyeweerd, H. A new critique of theoretical thought, 3 vol's (Df. I. II, III). Ansterdain, 1855.

Ea Eliot, TS. The idea of a christian society, London. Faber and Faber, 1962" (1931')

Eb Emmet. DM. The foundations of a free university, University Pamphlets nr 4, ed R H Preston. London. SCM Press, 1946.

Fa Fichte, J G. Deduzierter Plan einer zu Berlin zu errichtenden hohern Lehranstalt ...., hrsgg von E Spranger, Leipzig, Durr, 1910 , p 1-104.

Fb Forrester-Paton. C. Universities under fire, University Pamphlets nr 6, ed R H Preston, London, SCM Press, 1946.

Ga Gusdorf, G, Luniversite en question, Paris, Payot, 1964.

Gb Gusdorf, G, Les sciences de l'Homme sont-elles des sciences humaines?. Paris, Les Belles Lettres, 1967, p 265-204.

Hb Horkheimer, M. Frankfurter Universitétareden, Heft 8. Frankfurt aM, V Klostermann, 1953.

Hc Hoedemaker, $\mathrm{Ph}$ J, Het Anti-Revolutionair beginsel en het hooger onderwijs. Amsterdam. Höveker, 1883.

Ja Jaspers, K (und Rossmann, K), Die Idee der Universitat..., Berlin. Gottingen, Heidelberg. Springer Verlag, 1961.

Ka Kerr. C. The uses of the university, Cambridge Mass., Harvard Univ Press, 1863

Kb Kuyper, A. Band aan het woord ..., Amsterdam. Hoveker and Wormser, 1899.

Kc Kuyper, A. Soevereiniteit in eigen kring, Amsterdam. J H Kruyt. 1880.

Ma Moberley. W. The crisis in the university, London, SCM Press. 1849.

Nb Newman. J H. The Idea of the university, 1864.

Nc Notohamidjojo, O. The Necessity and Mission of Christian Universities in Modernizing Asia, in International Reformed Bulletis, 8 (October 1965), p 33-40.

Ra Hegtien, 'I'. Universiteit in opstand .... Amsterdam, Van Cennep. 1969.

Su Schleiermacher, F. Gelegentliche Gedanken über Universithten im deutschen Sinn ... (see $\mathrm{Fa})$, p 105-203.

Sr Schroff. KD. Die Universitat als Heilmittel. .... Wien. Brau. inuller. 1857.

Sk Symons. W G. Work and Vocation. University Pamphlets nr 10.ed HH Preston. London. SCM Press. 1946.

'l'n 'Tuljutrd, J A L, Akademiese vryheid, in Koers, XXXVII, nr6, 1038. p 425-444. 
Vc VonHumboldt, W, Werke, Darmstadt, WBG, Vol IV, p 225-286.

Ve Van Riessen, $H$, The university and its basis, Christian Perspectives Series, Ontario, ARSS, 1963.

Vi Visser 't Hooft, W A, A responsible university in a responsible society .... Cape Town. University of Capo Town, 1871.

Wa Wieruszowski, $H$, The mediaeval university: Masters, Students, Loarning, Princeton $\mathrm{H}$ J, Von Nostrand, 1868.

Za Zijlstra. O K, De Taak van de universiteit, deel II, unplished stencilled research report, Amsterdam, Free University, Philosophical Institute, Research Group "University', 1972. 